\title{
PERILAKU KEPALA DINAS DAN STANDAR NASIONAL PENDIDIKAN INDONESIA
}

\section{Kasus UPS, Polda Metro Periksa Mantan Kepala Dinas Pendidikan DKI}

Metrotvnews.com, Jakarta: Polda Metro Jaya memeriksa mantan Kepala Dinas Pendidikan DKI Jakarta Lasro Marbun. Pemeriksaan ini terkait kasus dugaan penyelewengan dana pengadaan alat uninterruptible power supply (UPS) pada APBD DKI 2014 di sekolah-sekolah wilayah Jakarta:

Lasro yang kini menjabat Kepala Inspektorat DKI Jakarta itu diperiksa oleh penyidik Subdit Tipikor Ditreskrimsus Polda Metro Jaya sebagai saksi dugaan korupsi pengadaan UPS saat ia masih menjabat sebagai Kepala Dinas Pendidikan DKI Jakarta.

"Saat ini ia masih diperiksa penyidik. Itu kaitannya dengan dia sebagai Kadisdik sewaktu pengadaan UPS," kata Kabid Humas Polda Metro Jaya Komisaris Besar Martinus Sitompul di Mapolda Metro Jaya, Rabu (11/3/2015).

Martinus mengatakan, Lasro diperiksa terkait perannya dalam pengadaan UPS di sekolah-sekolah. Sebagai Kadisdik DKI, menurut Martinus, Lasro seharusnya mengetahui soal perencanaan hingga berlangsungnya proyek tersebut.

Selain Lasro, hari ini penyidik juga memanggil 10 orang lainnya yang diperiksa sebagai saksi kasus pengadaan UPS. Namun, dari 10 orang tersebut, baru empat saksi yang hadir di antaranya Panitia Pemeriksa Hasil Pekerjaan (PPHP) Rani Murani dari Suku Dinas Pendidikan Menengah Jakarta Barat, Kepala Sekolah SMA 112 Jakarta Barat Saryono, dan Kepala Suku Dinas Pendidikan Menengah Jakarta Barat Ibnu Hajar.

Sejak meningkatkan status kasus ini dari penyelidikan menjadi penyidikan, Polda Metro Jaya telah memanggil 21 orang. Namun, baru 12 orang yang memenuhi panggilan tersebut.

Sebelumnya, Gubernur DKI Jakarta Basuki Tjahaja Purnama mengungkapkan adanya pencantuman dana "siluman" pada APBD DKI Jakarta 2014. Salah satu dugaan dana siluman yakni pengadaan UPS pada 49 sekolah yang menghabiskan dana sekitar Rp5,8 miliar per sekolah.

Ahok kembali mengungkap dalam usulan anggaran 2015, pengadaan UPS kembali disisipkan dalam RAPBD 2015. Total usulan anggaran "siluman" dalam APBD 2015 mencapai Rp12,1 triliun. Di dalamnya, juga terdapat anggran pengadaan UPS. Kali ini, pengadaan UPS tidak hanya untuk sekolah, tapi juga kantor kelurahan dan kecamatan.

Sumber: http://news.metrotvnews.com/read/2015/03/11/369703/kasus-ups-polda-metro-periksa-mantan-kepaladinas-pendidikan-dki

No 1: Bagaimana analisis Anda terkait kasus diatas jika dikaitkan dengan standar nasional pendidikan?

No 2 : factor apa saja yang dapat mempengaruhi kualitas pendidikan di suatu daerah? Jelaskan secara rinci! 
1. Bagaimana analisis Anda terkait kasus diatas jika dikaitkan dengan standar nasional pendidikan?

Pengertian Standar Nasional Pendidikan

Apa yang dimaksud dengan Standar Nasional Pendidikan (SNP)? Pengertian Standar Nasional

Pendidikan adalah suatu kriteria atau standar minimal terkait pelaksanaan sistem pendidikan yang ada di seluruh wilayah hukum Negara Kesatuan Republik Indonesia.

Fungsi dari Standar Nasional Pendidikan ini adalah sebagai dasar dalam melakukan perencanaan, pelaksanaan, dan pengawasan pendidikan untuk mewujudkan pendidikan nasional yang berkualitas.

Sedangkan tujuan utama dari Standar Nasional Pendidikan adalah untuk menjamin mutu pendidikan nasional dalam rangka mencerdaskan kehidupan bangsa, membentuk karakter dan peradaban bangsa yang bermartabat.

Standar Nasional Pendidikan (SNP) merupakan kriteria minimal tentang berbagai aspek yang relevan dalam pelaksanaan sistem pendidikan nasional dan harus dipenuhi oleh penyelenggara dan/atau satuan pendidikan di seluruh wilayah hukum Negara Kesatuan Republik Indonesia. Standar Nasional Pendidikan berfungsi sebagai dasar dalam perencanaan, pelaksanaan, dan pengawasan pendidikan dalam rangka mewujudkan pendidikan nasional yang bermutu. Standar Nasional Pendidikan bertujuan menjamin mutu pendidikan nasional dalam rangka mencerdaskan kehidupan bangsa dan membentuk watak serta peradaban bangsa yang bermartabat. Standar Nasional Pendidikan disempurnakan secara terencana, terarah, dan berkelanjutan sesuai dengan tuntutan perubahan kehidupan lokal, nasional, dan global.

\section{Standar Nasional Pendidikan}

Menurut penjelasan dari Badan Standar Nasional Pendidikan (BSNP), berikut ini adalah 8 standar pendidikan nasional di Indonesia:

\section{Standar Isi}

Hal-hal yang diatur dalam Standar Isi mencakup materi minimal dan tingkat kompetensi minimal untuk mencapai kompetensi lulusan minimal untuk jenis dan jenjang pendidikan tertentu. Di dalam Standar Isi terdapat kerangka dasar dan struktur kurikulum, beban belajar, kurikulum tingkat satuan pendidikan, dan kalender pendidikan.

Peraturan Menteri terkait Standar Isi:

- $\quad$ Permen No. 22 tahun 2006

- $\quad$ Permen No. 24 tahun 2006

- $\quad$ Permen No. 14 Tahun 2007 


\section{Standar Kompetensi Lulusan}

Pedoman penilaian dalam penentuan kelulusan peserta didik menggunakan Standar Kompetensi Lulusan untuk satuan pendidikan dasar dan menengah. Hal-hal yang diatur dalam Standar Kompetensi Lulusan (SKL) mencakup standar kompetensi lulusan minimal satuan pendidikan dasar dan menengah, standar kompetensi lulusan minimal kelompok mata pelajaran, dan standar kompetensi lulusan minimal mata pelajaran.

Peraturan Menteri terkait Standar Kompetensi Lulusan:

- $\quad$ Permen No. 23 Tahun 2006

- $\quad$ Permen No. 24 tahun 2006

Standar Kompetensi Lulusan (SKL) untuk satuan pendidikan dasar dan menengah digunakan sebagai pedoman penilaian dalam menentukan kelulusan peserta didik. Standar Kompetensi Lulusan meliputi standar kompetensi lulusan minimal satuan pendidikan dasar dan menengah, standar kompetensi lulusan minimal kelompok mata pelajaran, dan standar kompetensi lulusan minimal mata pelajaran. [2] Standar Kompetensi Lulusan meliputi:

1. SKL Satuan Pendidikan \& Kelompok Mata Pelajaran

2. SKL Mata Pelajaran SD-MI

3. SKL Mata Pelajaran SMP-MTs

4. SKL Mata Pelajaran SMA-MA

5. SKL Mata Pelajaran PLB ABDE

6. SKL Mata Pelajaran SMK-MAK

\section{Standar Proses Pendidikan}

Dalam pelaksanaan pembelajaran pada satuan pendidikan dilaksanakan secara interaktif, inspiratif, menantang, dan memotivasi peserta didik untuk aktif berpartisipasi. Proses belajarmengajar ini juga memberikan ruang bagi kreativitas, prakarsa, dan kemandirian sesuai dengan minat, bakat, dan perkembangan psikologis/ fisik para peserta didik.

Proses pembelajaran pada satuan pendidikan diselenggarakan secara interaktif, inspiratif, menyenangkan, menantang, memotivasi peserta didik untuk berpartisipasi aktif, serta memberikan ruang yang cukup bagi prakarsa, kreativitas, dan kemandirian sesuai dengan bakat, minat, dan perkembangan fisik serta psikologis peserta didik. Selain itu, dalam proses pembelajaran pendidik memberikan keteladanan. Setiap satuan pendidikan melakukan perencanaan proses pembelajaran, pelaksanaan proses pembelajaran, penilaian hasil pembelajaran, dan pengawasan proses pembelajaran untuk terlaksananya proses pembelajaran yang efektif dan efisien.

Peraturan Menteri terkait Standar Proses Pendidikan: 
- $\quad$ Permen No. 41 Tahun 2007

- $\quad$ Permen No. 1 Tahun 2008

- $\quad$ Permen No. 3 Tahun 2008

\section{Standar Sarana dan Prasarana}

Semua satuan pendidikan harus dilengkapi dengan sarana pendidikan seperti media pendidikan, peralatan pendidikan, buku dan sumber belajar lainnya, perabot, dan perlengkapan lainnya. Semua satuan pendidikan harus dilengkapi dengan prasarana pendidikan seperti lahan, ruang kelas, ruang pendidik, ruang pimpinan satuan pendidikan, ruang perpustakaan, dan prasarana pendukung lainnya.

Setiap satuan pendidikan wajib memiliki sarana yang meliputi perabot, peralatan pendidikan, media pendidikan, buku dan sumber belajar lainnya, bahan habis pakai, serta perlengkapan lain yang diperlukan untuk menunjang proses pembelajaran yang teratur dan berkelanjutan. Setiap satuan pendidikan wajib memiliki prasarana yang meliputi lahan, ruang kelas, ruang pimpinan satuan pendidikan, ruang pendidik, ruang tata usaha, ruang perpustakaan, ruang laboratorium, ruang bengkel kerja, ruang unit produksi, ruang kantin, instalasi daya dan jasa, tempat berolahraga, tempat beribadah, tempat bermain, tempat berkreasi, dan ruang/tempat lain yang diperlukan untuk menunjang proses pembelajaran yang teratur dan berkelanjutan.

Peraturan Menteri terkait Standar Sarana dan Prasarana:

- $\quad$ Permen No. 24 Tahun 2007

- $\quad$ Permen No. 33 Tahun 2008

- $\quad$ Permen No. 40 Tahun 2008

\section{Standar Pengelolaan}

Standar Pengelolaan mencakup tiga bagian, yaitu;

- Standar pengelolaan oleh satuan pendidikan.

- Standar pengelolaan oleh Pemerintah Daerah.

- Standar pengelolaan oleh Pemerintah.

Peraturan Menteri terkait Standar Pengelolaan:

- $\quad$ Permen No. 19 Tahun 2007

\section{Standar Pembiayaan Pendidikan}

Beberapa hal yang termasuk di dalam Standar Pembiayaan Pendidikan adalah biaya investasi, biaya operasi, dan biaya personal. 
- Biaya investasi satuan pendidikan mencakup biaya pengadaan prasarana dan sarana pendidikan, modal kerja tetap, dan pengembangan sumber daya manusia.

- Biaya operasi satuan pendidikan mencakup gaji tenaga pendidik, peralatan pendidikan, biaya pemeliharaan saran dan prasarana, pajak, asuransi, dan lain sebagainya.

- $\quad$ Biaya personal mencakup biaya pendidikan yang harus dibayar peserta didik agar dapat mengikuti proses belajar-mengajar.

Peraturan Menteri terkait Standar Pembiayaan Pendidikan:

- $\quad$ Permen No. 69 Tahun 2009

\section{Standar Penilaian Pendidikan}

Beberapa hal yang termasuk di dalam Standar Penilaian Pendidikan diantaranya penilaian hasil belajar oleh pendidik, penilaian hasil belajar oleh satuan pendidikan, dan penilaian hasil belajar oleh pemerintah.

Penilaian pendidikan pada jenjang pendidikan dasar terdiri atas: Penilaian hasil belajar oleh pendidik, Penilaian hasil belajar oleh satuan pendidikan, dan Penilaian hasil belajar oleh Pemerintah. Penilaian pendidikan pada jenjang pendidikan tinggi terdiri atas: Penilaian hasil belajar oleh pendidik, dan Penilaian hasil belajar oleh satuan pendidikan tinggi. Penilaian pendidikan pada jenjang pendidikan tinggi diatur oleh masing-masing perguruan tinggi sesuai peraturan perundang-undangan yang berlaku.

Peraturan Menteri terkait Standar Penilaian Pendidikan:

- $\quad$ Permen No. 20 Tahun 2007

\section{Standar Pendidik dan Tenaga Kependidikan}

Tenaga pendidik atau guru harus mempunyai kualifikasi akademik dan kompetensi sebagai agen pembelajaran, sehat rohani dan jasmani, serta mampu mewujudkan tujuan pendidikan nasional.

Pendidik harus memiliki kualifikasi akademik dan kompetensi sebagai agen pembelajaran, sehat jasmani dan rohani, serta memiliki kemampuan untuk mewujudkan tujuan pendidikan nasional. Kualifikasi akademik yang dimaksudkan adalah tingkat pendidikan minimal yang harus dipenuhi oleh seorang pendidik yang dibuktikan dengan ijazah dan/atau sertifikat keahlian yang relevan sesuai ketentuan perundang-undangan yang berlaku.

Pendidik meliputi pendidik pada TK/RA, SD/MI, SMP/MTs, SMA/MA, SDLB/SMPLB/SMALB, SMK/MAK, satuan pendidikan Paket A, Paket B dan Paket C, dan pendidik pada lembaga kursus dan pelatihan. Tenaga Kependidika meliputi kepala sekolah/madrasah, pengawas satuan pendidikan, tenaga administrasi, tenaga perpustakaan, tenaga laboratorium, teknisi, pengelola kelompok belajar, pamong belajar, dan tenaga kebersihan. 
Pendidik harus memiliki ijazah dan/ atau sertifikat keahlian sesuai dengan ketentuan perundangundangan yang berlaku. Adapun kompetensi yang harus dimiliki oleh tenaga pendidik adalah sebagai berikut:

- Kompetensi pedagogik

- Kompetensi kepribadian

- Kompetensi profesional

- Kompetensi sosial

Peraturan Menteri terkait Standar Pendidik dan Tenaga Kependidikan:

- $\quad$ Permen No. 12 Tahun 2007

- $\quad$ Permen No. 13 tahun 2007

- $\quad$ Permen No. 16 Tahun 2007

- $\quad$ Permen No. 24 Tahun 2008

- $\quad$ Permen No. 25 Tahun 2008

- $\quad$ Permen No. 26 Tahun 2008

- $\quad$ Permen No. 27 Tahun 2008

- $\quad$ Permen No. 40 - 45 Tahun 200

Fungsi dan Tujuan Standar Nasional Pendidikan

Seperti yang sudah disebutkan pada paragraf awal sebelumnya, fungsi dan tujuan utama dari Standar Nasional Pendidikan ini adalah sebagai dasar pelaksanaan pendidikan di Indonesia. Berikut penjelasan selengkapnya:

1. Standar Nasional Pendidikan memiliki fungsi sebagai acuan atau dasar dalam proses perencanaan, pelaksanaan, dan pengawasan demi untuk mewujudkan pendidikan nasional yang berkualitas.

2. Standar Pendidikan Nasional bertujuan untuk memberikan jaminan pendidikan nasional yang bermutu dalam rangka mencerdaskan kehidupan bangsa, membentuk karakter, serta peradaban bangsa yang bermartabat.

3. Standari Nasional Pendidikan diselenggarakan secara terencana, terarah, dan berkesinambungan sesuai dengan kebutuhan dan perubahan kehidupan nasional dan global.

Itulah penjelasan ringkas mengenai Standar Nasional Pendidikan (SNP) serta fungsi dan tujuannya. Semoga artikel ini bermanfaat dan menambah wawasan kamu.

2. factor apa saja yang dapat mempengaruhi kualitas pendidikan di suatu daerah? Jelaskan secara rinci! 
Semakin tertinggalnya pendidikan bangsa ini dari bangsa-bangsa lain harusnya membuat kita lebih termotivasi untuk berbenah diri. Banyaknya masalah pendidikan yang muncul semakin kompleks seiring dengan berkembangnya zaman. Berikut ini secara khusus akan saya paparkan beberapa faktor yang menyebabkan kualitas pendidikan di Indonesia rendah.

\section{Rendahnya Kualitas Sarana Fisik}

Untuk sarana fisik, banyak sekali lembaga pendidikan di Indonesia yang tidak layak untuk digunakan. Banyak pula sekolah dan perguruan tinggi kita yang gedungnya rusak, atau bahkan masih ada lembaga pendidikan yang belum memiliki gedungnya sendiri, kepemilikan dan penggunaan media belajar rendah, serta buku perpustakaan yang tidak lengkap. Sementara laboratorium tidak sesuai standar, pemakaian teknologi informasi tidak memadai dan sebagainya. Nanang Fatah, seorang pakar pendidikan Universitas Pendidikan Indonesia (UPI) mengatakan sekitar $60 \%$ bangunan sekolah di Indonesia rusak berat. Di wilayah Jawa Barat, sekolah yang rusak mencapai $50 \%$.

Data Balitbang Depdiknas (2003) menyebutkan untuk satuan SD terdapat 146.052 lembaga yang menampung 25.918 .898 siswa serta memiliki 865.258 ruang kelas. Dari seluruh ruang kelas tersebut sebanyak 364.440 atau 42,12 \% berkondisi baik, 299.581 atau 34,62 \% mengalami kerusakan ringan, dan sebanyak 201.237 atau 23,26 \% mengalami kerusakan berat. keadaan yang serupa juga terjadi di SMP, MTs, SMA, dan SMK akan tetapi prosentasenya tidak sama.

\section{Rendahnya Kualitas Guru}

Keadaan guru di Indonesia juga memprihatinkan. Kebanyakan guru belum memiliki profesionalisme yang memadai untuk menjalankan tugasnya sebagaimana telah disebutkan dalam pasal 39 UU No. 20 / 2003 yaitu merencanakan pembelajaran, melakukan pembimbingan, melakukan perhatian, melakukan penelitian dan melakukan pengabdian masyarakat. Prosentase guru menurut kelayakan mengajar dalam tahun 2002-2003 di berbagai satuan pendidikan adalah sebagai berikut : untuk SD yang layak mengajar hanya 21,07\% (negeri) dan $28,94 \%$ (swasta), untuk SMP 54,12 \% ( negeri) dan 60,99 \% (swasta), untuk SMA 65,29 \% (negeri) dan 64,73\% (swasta), serta untuk SMK yang layak mengajar 55,49\% (negeri) dan $58,26 \%$ (swasta).

Walaupun guru atau pengajar bukanlah satu-satunya faktor penentu keberhasilan pendidikan tetapi pengajaran merupakan titik sentral pendidikan dan kualifikasi. Sebagai cermin kualitas, tenaga pengajar memiliki andil yang sangat besar pada kualitas pendidikan yang menjadi tanggung jawabnya.

\section{Rendahnya Kesejahteraan Guru}

Rendahnya kesejahteraan guru mempengaruhi peran dalam membuat kualitas pendidikan di Indonesia. Berdasarkan survei FGII (Federasi Gur Independen Indonesia) pada pertengahan tahun 2005, idealnya seorang guru menerima gaji bulanan sebesar Rp. 3.000.000,00. Sekarang pendapatan rata-rata guru perbulannya sebesar Rp. 1.500.000,00. Guru bantu Rp. 460.000,00 dan guru honorer di sekolah swasta rata-rata Rp. 10.000,00 per jam. 
Dengan pendapatan seperti itu, terang saja banyak guru-guru yang melakukan pekerjaan sampingan. Ada yang mengajar lagi di sekolah lain, memberi les pada sore hari, menjadi tukang ojek, pedagang mi rebus, pedagang buku/LKS, pedagang pulsa ponsel, dan sebagainya (Republika, 13 Juli 2005).

Selain itu kesenjangan guru swasta dan negeri menjadi masalah lain yang muncul. Di lingkungan pendidikan swasta, masalah kesejahteraan guru masih sulit mencapai taraf ideal. Sebanyak $70 \%$ dari 403 PTS di Jawa Barat dan Banten tidak sanggup untuk menyesuaikan kesejahteraan dosen sesuai dengan amanat UU Guru dan Dosen (Pikiran Rakyat, 9 Januari 2006).

Mengapa kesejahteraan guru menjadi hal yang berpengaruh terhadap kualitas pendidikan di Indonesia? Hal ini penting dan berpengaruh jika kesejahteraan seorang pengajar belum terpenuhi, kemungkinan besar akan sulit bagi pengajar untuk menyampaikan bahan ajar terhadap peserta didik dengan optimal karena bisa saja motivasi mereka untuk mentransfer ilmu menjadi berkurang. Dan konsentrasi pendidik pun lebih mengarah terhadap bagaimana memenuhi kebutuhannya sendiri.

\section{Rendahnya Prestasi Siswa}

Dengan keadaan-keadaan di atas, pencapaian prestasi siswa pun menjadi kurang memuaskan. Sebagai misal pencapaian prestasi fisika dan matematika siswa Indonesia di dunia internasional sangat rendah. Menurut Trends in Mathematics and Science Study (TIMSS) 2003 (2004), siswa Indonesia hanya berada di peringkat ke-35 dari 44 negara dalam hal prestasi matematika dan berada di peringkat ke-37 dari 44 negara dalam hal prestasi sains.

Namun bukan berarti bahwa anak-anak di Indonesia bodoh. Pada dasarnya tidak ada anak yang bodoh. Yang ada adalah anak yang rajin dan yang kurang rajin.

Jika ditarik suatu garis hubungan, tinggi atau tidaknya motivasi belajar dari para siswa ini bisa juga disebabkan oleh faktor-faktor eksternal yang tidak akan diulas secara mendalam dalam makalah ini.

\section{Mahalnya Biaya Pendidikan}

"Pendidikan bermutu itu mahal". Kalimat ini sering muncul untuk menjustifikasi mahalnya biaya pendidikan. Mahalnya biaya pendidikan dari taman kanak-kanak (TK) hingga Perguruan Tinggi (PT) membuat masyarakat yang kurang mampu tidak memilii pilihan lain selain tidak bersekolah.

Sebenarnya jika kita membandingkan dengan negara-negara lain untuk menempuh pendidikan di luar negeri jauh lebih mahal dibandingkan dengan biaya pendidikan kita. Namun mengapa rakyat masih menganggap biaya pendidikan di Indonesia tergolong sangat mahal? Tentu saja hal tersebut dapat terjadi mengingat keadaan ekonomi negara kita saat ini.

\section{Masalah Kurikulum}


Ada kekurangan yang dapat kita rangkum secara global dalam konteks pendidikan perihal kurikulum. Pertama, kurikulum pendidikan di Indonesia yang kurang menekankan pentingnya studi yang dalam dan berkelanjutan mengenai wawasan nusantara. Hal ini terbukti dengan kurangnya sorotan lembaga pendidikan terhadap alokasi waktu mata pelajaran khususnya Kewarganegaraan yang dalam realisasinya hanya mendapat sorotan selama 2 s/d 2,5 jam per minggunya.

Hal tersebut akan berdampak pada kurangnya jiwa nasionalisme dari peserta didik. Hal ini akan merugikan bangsa karena pada saat peserta didik memasuki dunia kerja. Orientasi utama mereka mungkin lebih mengarah terhadap materi dan bukannya member kontribusi terhadap negara. Kedua, kurikulum pendidikan di Indonesia dari segi pengajaran kita yang kurang mengarahkan peserta didik untuk nantinya jika telah lulus menempuh pendidikan formal untuk menciptakan sesuatu. Hal ini akan membentuk kepribadian yang konsumtif.

\section{PERANAN PEMERINTAH DALAM PENINGKATAN KUALITAS PENDIDIKAN DI INDONESIA}

Dari uraian tentang beberapa permasalahan pendidikan secara khusus di atas, pemerintah telah memberikan beberapa solusi untuk mengatasinya. Solusi tersebut, yang akan saya paparkan, ada yang telah terlaksana dan ada yang dalam proses karena memiliki jangka waktu berkala atau menjadi sebuah terapan setiap tahunnya. Solusi permasalahan tersebut adalah :

\section{Rendahnya Sarana Fisik}

Pemerintah setiap tahunnya telah berusaha meningkatkan anggaran untuk pendidikan. Dan tentu saja sasarannya adalah agar seluruh masyarakat Indonesia bisa menikmati pendidikan yang bermutu dengan kondisi yang mendukung.

\section{Rendahnya Kualitas Guru}

Pemerintah mulai aktif dalam pemberian bekal, penyuluhan, lokakarya, dan sebagainya untuk meningkatkan kualitas pendidik di Indonesia. Terbukti saat ini seluruh Pegawai Negeri Sipil yang telah atau sedang mengajar, harus bergelar S1. Ini berarti, mau tidak mau bagi pengajar yang bergelar diploma harus menempuh pendidikan lanjutan untuk mendapat gelar Sarjana dan secara otomatis, mereka akan mendapatkan ilmu yang lebih pula. Dan diharapkan dengan kebijakan ini, pengajar di Indonesia dapat lebih meningkat kualitasnya.

\section{Randahnya Kesejahteraan Guru}

Rendahnya kesejahteraan guru sangat berkaitan dengan rendahnya kualitas guru dan kualitas pendidikan di Indonesia. Pemerintah sendiri telah menjalankan program Sertifikasi Guru yang sasarannya adalah semua Pegawai Negeri Sipil lebih khususnya adalah guru. Sertifikasi ini tidak dilaksanakan dengan serentak namun secara berkala dengan maksud, guru yang pengangkatannya lebih lama mendapat giliran terlebih dahulu dan selanjutnya guru-guru lainnya. 
Dengan diadakannya sertifikasi ini, kesejahteraan guru pun akan meningkat sekaligus kualitas mereka juga akan meningkat. Karena, bagi guru yang tidak lulus sertifikasi, akan diberikat diklat atau semacam pelatihan yang pada akhirnya akan lulus juga. Namun, bukan hanya sekedar lulus, tujuan dari diklat itu adalah memberikan bekal agar kualitas guru saat kembali mengajar semakin meningkat. Dengan demikian, dua masalah yang ada dapat diberikan suatu solusi sekaligus.

\section{Rendahnya Prestasi Siswa}

Untuk meningkatkan motivasi siswa agar prestasi mereka meningkat, pemerintah setiap tahunnya selalu meningkatkan standar kelulusan minimal yang harus dicapai siswa. Hal ini dimaksudkan agar dengan naiknya standar kelulusan minimal siswa dapat lebih rajin dan lebih giat lagi belajar untuk mencapai standar tersebut.

\section{Mahalnya Biaya Pendidikan}

Untuk masalah ini, pemerintah telah mencanangkan program BOS (Bantuan Operasinal Siswa). Dengan BOS, pendidikan di Indonesia dapat dinikmati oleh semua kalangan (walaupun masih sampai jenjang SMP). Namun, saat ini juga telah banyak lembaga-lembaga yang memberikan beasiswa untuk siswa yang berprestasi maupun untuk siswa yang tidak mampu. Dengan adanya hal itu, kerja sama antara pemerintah dengan pihak-pihak yang menyelenggarakan hal tersebut dapat meningkatkan motivasi belajar dari siswa itu sendiri. Selain itu, adanya program ini tentu saja bukti realisasi dan keseriusan pemerintah agar seluruh rakyatnya dapat menikmati pendidikan.

\section{Masalah Kurikulum}

Untuk mengatasi masalah kurikulum yang ada, pemerintah telah berusaha untuk mengganti kurikulum yang dianggap kurang tepat dan kurang efisien dengan kurikulum baru yang dianggap lebih efisien. Contohnya pada tahun 2004, pemerintah telah mengganti kurikulum 1994 dengan Kurikulum Berbasis Kompetensi, dan saat ini kurikulum sudah berganti menjadi KTSP (Kurikulum Satuan Tingkat Pendidikan).

Dari uraian sederhana di atas cukup memberikan bukti bahwa pemerintah tidak pernah mainmain dalam urusan pendidikan di Indonesia terutama untuk pengingkatan kualitas pendidikannya. Walaupun pada kenyataannya kebijakan-kebijakan di atas memunculkan pro dan kontra di berbagai kalangan. Namun pemerintah terus berusaha dengan menerapkan upaya-upaya untuk meningkatkan kualitas pendidikan di Indonesia.

Presiden Susilo Bambang Yudhoyono pun tidak pernah menutup mata akan permasalahanpermasalahan pendidikan yanga ada saat ini. Butuh pemikiran yang sangat rumit untuk menyelesaikan dan mencari solusi terbaik dari masalah ini. Karena sudah pasti kebijakan pemerintah sekecil apaun akan menimbulkan pro dan kontra di berbagai pihak. "Pendidikan ini menjadi tenggung jawab pemerintah sepenuhnya", kata Presiden Susilo Bambang Yudhoyono usai rapat kabinet terbatas di Gedung Depdiknas Jl. Jendral Sudirman, Jakarta, Senin (12/3/2007). 
Presiden memaparkan langkah yang akan ditempuh oleh pemerintah dalam rangka meningkatkan kualitas pendidikan di Indonesia, antara lain yaitu :

- $\quad$ Langkah pertama yang akan dilakukan pemerintah, yakni meningkatkan akses terhadap masyarakat untuk bisa menikmati pendidikan di Indonesia. Tolak ukurnya dari angka partisipasi.

- $\quad$ Langkah kedua, mengatasi ketidakmerataan dalam akses pendidikan seperti ketidak merataan di desa dan kota, serta jender.

- Langkah ketiga, meningkatkan mutu pendidikan dengan meningkatkan kualifikasi guru dan dosen serta meningkatkan nilai rata-rata kelulusan dalam Ujian Nasional.

- $\quad$ Langkah keempat, pemerintah akan menambah jenis pendidikan di bidang kompetensi atau profesi sekolah kejuruan untuk menyiapkan tenaga siap pakai yang dibutuhkan.

- $\quad$ Langkah kelima, pemerintah merencanakan pembangunan infrastruktur seperti menambah jumlah komputer dan perpustakaan sekolah.

- Langkah keenam pemerintah juga meningkatkan anggaran pendidkan. Untuk tahun ini dianggarkan sebanyak 4,4 trilliun.

- Langkah ketujuh, menggunakan teknologi informasi dalam aplikasi pendidikan.

- Langkah terakhir adalah pembiayaan masyarakat miskin untuk bisa menikmati fasilitas pendidikan.

\section{PERAN PEMERINTAH DALAM MENINGKATKAN MUTU PENDIDIKAN MENURUT UUD}

Pembukaan Undang-Undang Dasar Negara Republik Indonesia tahun 1945 (UUD 1945) mengamanatkan bahwa Pemerintah Negara Indonesia harus melindungi segenap bangsa Indonesia dan seluruh tumpah darah Indonesia dan untuk memajukan kesejahteraan umum, mencerdaskan kehidupan bangsa, dan ikut melaksanakan ketertiban dunia yang berdasarkan kemerdekaan, perdamaian abadi dan keadilan sosial. Dengan demikian, Pemerintah diwajibkan untuk mengusahakan dan menyelenggarakan satu sistem pendidikan nasional bagi seluruh warga negara Indonesia.

Sistem pendidikan nasional dimaksud harus mampu menjamin pemerataan kesempatan dan peningkatan mutu pendidikan, terutama bagi anak-anak, generasi penerus keberlangsungan dan kejayaan Bangsa dan Negara Kesatuan Republik Indonesia (NKRI). Upaya yang telah dilakukan oleh pemerintah melalui berbagai paket program pendidikan sebagai impelementasi penggunaan 
anggaran pendidikan $20 \%$ dari APBN, utamanya di daerah-daerah tertinggal masih sangat minim dibandingkan dengan kebutuhan masyarakat. Program-program yang dibuat oleh pemerintah seringkali hanya program tambal sulam (incremental) dan tidak berkelanjutan (sustainable).

Banyaknya sekolah, utamanya sekolah dasar yang dalam kondisi rusak berat dan hanya direhabilitasi melalui Biaya Orientasi Sekolah (BOS) dan berbagai paket program sejenis lainnya, tidaklah menjadikan sarana dan prasarana pendidikan tersebut menjadi lebih baik. Banyaknya sekolah dasar yang rusak tersebut menyebabkan anak-anak usia pendidikan dasar tidak merasa nyaman dalam proses pembelajaran. Padahal untuk anak-anak usai tersebut, dukungan sarana dan prasarana yang memadai amat dibutuhkan guna menunjang keberhasilan pendidikannya. Pemerintah memegang peranan penting dalam meningkatkan kualitas pendidikan anak-anak Indonesia, utamanya mulai dari ketersediaan sarana dan prasarana minimal berupa gedung sekolah yang layak, hingga sampai pada ketersediaan berbagai fasilitas pendukung pendidikan lainnya.

Bagi sekolah-sekolah yang berada di perkotaan, sekolah yang rusak berat dan masih belum direhabilitasi sangat banyak ditemui, apalagi di daerah-daerah terpencil di Indonesia. Dengan kata lain, sekolah-sekolah diperkotaan saja kondisinya masih demikian, apalagi di pelosok Indonesia. Selain ketersediaan sarana dan prasarana fisik dan berbagai fasilitas pendukung pendidikan lainnya yang masih terbatas dan belum menjangkau seluruh wilayah NKRI, kurikulum pendidikan dasar pun menjadi permasalahan. Kurikulum yang seringkali berubah seiring dengan pergantian rezim pemerintahan menyebabkan anak-anak usia sekolah dasar menjadi korbannya. Anak-anak usia sekolah dasar merupakan anak-anak yang mind set berfikirnya belum terbentuk, anak-anak tersebut masih dalam tahap amati dan tiru, belum sampai tahap modifikasi. Selain itu, beban kurikulum yang berat menyebabkan anak-anak kehilangan kreativitasnya karena hanya dibebani dengan mata pelajaran yang terkonsep dan berpola baku secara permanen. Artinya, apa yang di dapat di sekolah, itulah yang ada pada dirinya, tanpa kecuali.

Pemerintah harus menyadari bahwasannya anak-anak merupakan investasi masa depan sebuah bangsa. Merekalah yang kelak akan mengisi ruang-ruang proses berbangsa dan bernegara. Wajar saja ketika banyak orang menyerukan bahwa anak adalah bibit-bibit atau tunas yang harus diperhatikan dan dirawat dengan baik. Merekalah pewaris masa depan, tulang punggung dan harapan bangsa dan negara ada di pundak mereka. Namun, harapan itu ternyata masih membentur tembok yang sangat besar. Ternyata masih banyak di temukan anak-anak kurang mampu harus berhenti sekolah karena tidak memiliki biaya. Sering dijumpai bahwa anak-anak Indonesia harus dipaksa mengemis demi menghidupi keluarga, melakukan tindak kriminal dan terlantar karena ketimpangan ekonomi. Tidak jarang pula anak-anak seringkali menghadapi bentuk-bentuk kekerasan baik fisik maupun non fisik. Padahal, anak-anak Indonesia harusnya berada di rumah, belajar dengan baik dan menikmati tugas-tugas bagi tumbuh kembang diri 
mereka. Disinilah peran pemerintah harus ditingkatkan dalam rangka peningkatan pendidikan anak-anak Indonesia.

Pendidikan Karakter merupakan proses pemberian tuntunan peserta/anak didik agar menjadi manusia seutuhnya yang berkarakter dalam dimensi hati, pikir, raga, serta rasa dan karsa. Peserta didik diharapkan memiliki karakter yang baik meliputi kejujuran, tanggung jawab, cerdas, bersih dan sehat, peduli, dan kreatif. Pemerintah melalui Kemendiknas meluncurkan sebuah program pendidikan, yang dikenal dengan Pendidikan Karakter. Dominasi ranah kognitif dan psikomotorik harus dikurangi, ranah afektif sudah seharusnya menjadi fokus utama. Sehingga terbentuklah manusia-manusia yang berkarakter luhung, berbudi pekerti tinggi. Manusiamanusia seperti inilah yang diharapkan mampu membawa bangsa Indonesia menjadi jauh lebih baik, menjadikan Indonesia sebagai bangsa yang berbudaya tinggi. Pendidikan karakter dibutuhkan untuk mencegah setiap perbuatan-perbuatan yang tidak baik yang dapat merusak pendidikan di Indonesia. Oleh karena itu, semua peran sangat dibutuhkan untuk memajukan sistem pendidikan di Indonesia agar pendidikan di Indonesia mengalami pemerataan, peningkatan dan perubahan yang signifikan. Pendidikan Karakter bertujuan untuk memberikan pengetahuan tentang hal yang baik dan buruk, kemudian membuat hal yang baik menjadi suatu kebiasaan.

Budaya ini harus dipelihara agar pendidikan di Indonesia berkembang dan bisa menjadi daya saing bagi pendidikan lainnya secara global. Pendidikan memegang peranan yang sangat penting dalam proses peningkatan kualitas sumber daya manusia dan merupakan suatu proses yang terintegrasi dengan proses peningkatan kualitas sumber daya manusia itu sendiri. Menyadari pentingnya proses peningkatan kualitas sumber daya manusia, maka Pemerintah telah berupaya mewujudkan amanat tersebut melalui berbagai usaha pembangunan pendidikan yang lebih berkualitas melalui pengembangan dan perbaikan kurikulum dan sistem evaluasi, perbaikan sarana pendidikan, pengembangan dan pengadaan materi ajar, serta pelatihan bagi guru dan tenaga kependidikan lainnya. Tetapi kenyataan belum cukup dalam meningkatkan kualitas pendidikan.

\section{KESIMPULAN}

Keadaan kualitas pendidikan di Indonesia sangat memprihatinkan. Data-data yang ada menunjukkan bahwa Indonesia mengalami keterpurukan dalam hal kualitas pendidikan. Faktorfaktor yang mempengaruhi kualitas penddikan sangat banyak dan kompleks. Namun pada makalah ini hanya saya sebutkan sebagian kecil saja, antara lain :

- $\quad$ rendahnya kualitas sarana fisik,

- rendahnya kualitas guru, 
- $\quad$ rendahnya kesejahteraan guru,

- mahalnya biaya pendidikan, dan

- $\quad$ masalah kurikulum yang kurang efektif

Dari faktor-faktor yang telah disebutkan pemerintah telah mengambil langkah tegas untuk mengatasinya, antara lain :

- meningkatkan anggara pendidikan,

- mengadakan pembinaan, lokakarya, penyuluhan, pelatihan bagi guru dan pendidik,

- $\quad$ mengadakan sertifikasi guru setiap tahunnya,

- meningkatkan nilai rata-rata kelulusan dalam Ujian Nasional,

- $\quad$ pengadaan Program BOS, dan

- $\quad$ mengganti kurikulum.

\section{B. SARAN}

Agar kualitas pendidikan di Indonesia dapat meningkat, perlu adanya kerja sama dari berbagai pihak. Baik itu dari pemerintah maupun dari masyarakat sebagai pelaku dan penikmat pendidikan. Peran serta masyarakat dalam kemajuan kualitas pendidikan di negara ini sangat diharapkan agar tercipta suatu hubungan timbal balik yang baik antara pemerintah dan masyarakat.

Pemerintahpun harus bisa meningkatkan birokrasi negara ini agar semua kebijakan yang diambil menyangkut peningkatan kualitas pendidikan di Indonesia dapat berjalan dengan lancar dan dapat meminimalisir hambatan yang mungkin muncul.

\section{REFERENSI}

Manurung, T.M.S., 2017. Pengaruh Motivasi dan Perilaku Belajar Terhadap Prestasi Akademik Mahasiswa. JAS-PT Jurnal Analisis Sistem Pendidikan Tinggi, 1(1), pp.17-26.

Cahyana, R. and Sagala, I., 2017. Model Sistem Perubahan dalam Lingkup Program Sarjana. JAS-PT Jurnal Analisis Sistem Pendidikan Tinggi, 1(1), pp.47-52.

Sastra, H., 2018. Minat Berinvestasi Mahasiswa dan Kualitas Pelayanan Gerai Bursa Efek Indonesia STIE Kesatuan Bogor. JAS-PT Jurnal Analisis Sistem Pendidikan Tinggi, 2(1), pp.1-12.

Astuti, S.P. and Utami, D.E., 2018. Pengembangan Kualitas Perguruan Tinggi Islam Berdasarkan Keinginan dan Kebutuhan Stakeholder. JAS-PT (Jurnal Analisis Sistem Pendidikan Tinggi Indonesia), 2(2), pp.71-82.

Ariffin, M., Suharmiati, S. and Amwilla, A.Y., 2018. Persepsi Mahasiswa Atas Kualitas 
Pelayanan Laboratorium Bank Mini STIE Kesatuan dan Implikasinya Terhadap Kepuasan Mahasiswa. JAS-PT Jurnal Analisis Sistem Pendidikan Tinggi, 2(1), pp.13-18.

Lazarus, D., 2018. Student Self-Responsibility in the Indonesian Distance Education System. JAS-PT Jurnal Analisis Sistem Pendidikan Tinggi, 1(2), pp.69-78.

Iriyadi, I., Pamungkas, B. and Gunawan, L.G., 2015. Sistem Informasi Akuntansi Dalam Kaitannya Dengan Laporan Biaya Produksi Pada Perusahaan CV Surya Pratama Gemilang. Jurnal Ilmiah Akuntansi Kesatuan, 3(3).

Pamungkas, B., 2008. Akuntabilitas Instansi Pemerintah, Survei Pada Pemerintah Dati II DI Yogyakarta.

Purba, J.H.V. and Munawar, A., 2008. Kajian Dampak Pelatihan terhadap Kinerja Karyawan. Jurnal Ilmiah Ranggagading (JIR), 8(2), pp.95-102. 